\title{
KUALITAS BULIR CAIRAN Caulerpa racemosa YANG DISALUT DENGAN Na-ALGINAT DAN Ca-LAKTAT
}

\section{The Quality of Caulerpa racemosa Liquid Grain Encapsulated with Na-Alginate and Ca-Lactate}

\author{
Jamal Basmal dan Nurhayati \\ Balai Besar Riset Pengolahan Produk dan Bioteknologi Kelautan dan Perikanan, \\ JI. KS Tubun, Petamburan VI, Jakarta Pusat, 10260 Indonesia \\ *Korespondensi Penulis: jamalbasmal24@gmail.com \\ Diterima: 28 Mei 2020; Direvisi: 17 Agustus 2020; Disetujui: 16 November 2020
}

\begin{abstract}
ABSTRAK
Caulerpa racemosa mengandung serat, vitamin, antioksidan, polisakarida sulfat, sulfat bebas, dan mineral sehingga dapat dimanfaatkan sebagai pangan fungsional. Namun, cairan $C$. racemosa mudah mengalami kemunduran mutu selama proses penyimpanan dan transportasi, sehingga perlu dipertahankan mutunya dalam bentuk bulir. Perlakuan yang diberikan dalam proses penyalutan adalah variasi konsentrasi $\mathrm{Na}$-alginat $0,4 \% ; 0,6 \%$; dan $0,8 \%$ dan variasi larutan Ca-laktat $0,4 \% ; 0,6 \%$; dan $0,8 \%$ yang diulang sebanyak tiga kali. Tujuan penelitian ini untuk menentukan kombinasi konsentrasi $\mathrm{Na}$-alginat dan $\mathrm{Ca}$-laktat terbaik dalam mempertahankan mutu bulir cairan $C$. racemosa. Hasil penelitian menunjukkan bahwa cairan $C$. racemosa mengandung mineral, serat pangan, dan asam amino, baik esensial maupun non esensial dengan kadar air cairan $C$. racemosa sebesar $97,77 \% \pm 0,02 \%$ dan setelah ditambah air dengan rasio 1:4, kadar airnya menjadi 99,6\% $\pm 0,61 \%$. Perlakuan konsentrasi Ca-laktat berpengaruh terhadap kadar air dan kadar abu bulir yang dihasilkan, sementara kadar serat kasar bulir dipengaruhi oleh perbedaan konsentrasi $\mathrm{Na}$-alginat. Nilai terbaik berdasarkan kadar serat ditemukan pada perlakuan kombinasi $\mathrm{Na}$-alginat $0,6 \%$ dan $\mathrm{Ca}$-laktat $0,8 \%$, yaitu sebesar $4,05 \%$ dengan kadar air $97,22 \%$ dan kadar abu $0,65 \%$.
\end{abstract}

KATA KUNCI : rumput laut, bulir, Caulerpa racemosa, kalsium laktat, natrium alginat

\section{ABSTRACT}

Caulerpa racemosa contains fiber, vitamins, antioxidants, sulfated polysaccharides, free sulfates, and minerals so that it can be used as functional food. However, $\underline{\underline{C}}$ racemosa liquid deteriorates easily during storage and transportation, therefore it is necessary to maintain the quality of $\underline{\underline{C}}$. racemosa liquid in encapsulated form as grain. The treatments given in encapsulation process were variation of $\mathrm{Na}$-alginat concentration i.e. $0.4 \%$; $0.6 \%$; and $0.8 \%$, and variation of $\mathrm{Ca}$ lactate solution i.e. $0.4 \% ; 0.6 \%$; and $0.8 \%$ which were repeated three times. The aim of the study was to determine the best combination of $\mathrm{Na}$-alginate and Ca-lactate concentrations in maintaining the quality of encapsulated $\underline{\underline{C}}$. racemosa liquid grain. The results showed that $\underline{\underline{C}}$ racemosa liquid contained minerals, dietary fiber and amino acids, both essential and non-essential, with moisture content of $97.77 \pm 0.02 \%$. After added with water with a ratio of $1: 4$, the moisture content of $\underline{C}$. racemosa liquid was $99.6 \% \pm 0.61 \%$. The treatment of $\mathrm{Ca}$-lactate concentration affected the moisture content and ash content of the liquid grain, while the crude fiber content was affected by Naalginate concentration. The best value based on fiber content was found in the combination treatment of $0.6 \% \mathrm{Na}$-alginate and $0.8 \%$ Ca-lactate (A6K8) at $4.05 \%$, with moisture content of $97.22 \%$ and an ash content of $0.65 \%$.

\section{KEYWORDS: seaweed, grain, Caulerpa racemosa, calcium lactate, sodium alginate}

\section{PENDAHULUAN}

Caulerpa racemosa merupakan salah satu jenis rumput laut hijau dari genus Caulerpa. Rumput laut ini memiliki ramuli berbentuk bulatan-bulatan seperti buah anggur, sehingga sering disebut dengan anggur laut. Caulerpa mengandung serat, vitamin, antioksidan, polisakarida sulfat total $(2,2 \%)$, sulfat bebas $(15,17 \%)$, dan mineral seperti P, Mg, Ca, dan Cu (de Gaillande, Payri, Remoissenet, \& Zubia, 2017; Khan, Athar, Viqar, \& Ara, 2012; Matanjun, Mohamed, Mustapha, \& Muhammad, 2009; Ratana-arporn \& Chirapart, 2006). 
Secara umum, rumput laut kaya akan mikromineral dan vitamin, sedangkan kandungan polisakarida, selulosa, hemiselulosa, dan ligninnya tidak dapat sepenuhnya dicerna oleh manusia dan dianggap sebagai sumber serat pangan yang dapat mencegah obesitas dan penyakit degeneratif (Mabeau \& Fleurence, 1993; Ortiz et al., 2006; SánchezMachado, López-Cervantes, López-Hernández, \& Paseiro-Losada, 2004; Santoso, Yoshie-Stark, \& Suzuki, 2004).

Dalam ekstrak cairan $C$. racemosa, ditemukan asam lemak tak jenuh ganda, tak jenuh tunggal, terpenoid, dan alkaloid yang dapat menjadi sumber antioksidan dan antibakteri baru dari hasil laut (Yap, Tay, Tan, Yow, \& Chew, 2019). Menurut Santoso, Yoshie, \& Suzuki (2002), Caulerpa segar memiliki aktivitas antioksidan dengan nilai $I C_{50}$ (Inhibition Concentration) $452,37 \pm 8,29$ ppm, serta mengandung galokatekin, epikatekin, dan katekin yang merupakan senyawa turunan fenol. Senyawa fenol dengan gugus hidroksil terikat pada cincin aromatik merupakan senyawa yang efektif sebagai antioksidan karena mampu meredam radikal bebas dengan cara memberikan atom hidrogen (donor elektron) dari gugus hidroksil kepada radikal bebas, namun rentan terhadap perubahan suhu (Tamat, Wikanta, \& Maulina, 2007). Komponen aktif ini diduga memiliki efek sinergi yang berperan sebagai antioksidan.

C. racemosa mudah mengalami kemunduran mutu selama proses penyimpanan dan transportasi. Cairan dalam rumput laut mudah sekali keluar dari dalam talusnya sehingga terjadi penurunan mutu. Untuk itu, perlu adanya pengolahan lebih lanjut menjadi bentuk olahan pangan seperti bulir Caulerpa. Bulir Caulerpa adalah olahan dari rumput laut Caulerpa yang berbentuk bulatan-bulatan kecil mirip dengan ramuli dari anggur laut. Proses pembentukan bulir cairan $C$. racemosa dapat dilakukan dengan menambahkan $\mathrm{Na}$ alginat ke dalam cairan $C$. racemosa yang kemudian direaksikan dengan ion $\mathrm{Ca}^{2+}$ sehingga terbentuk bulir. Alginat dapat berfungsi sebagai pengental, pengemulsi, pembentuk gel, stabilizer, dan binder pada berbagai jenis produk pangan (Aristya, Admadi, \& Arnata, 2017; Kasim, Marzuki, \& Sudir, 2017; Mushollaeni \& Rusdiana, 2011; Pamungkas, Ridlo, \& Sunaryo, 2013; Subaryono, 2010; Sukma, Harsojuwono, \& Arnata, 2017; Utomo et al., 2014). Bulir cairan C. racemosa tidak dapat terbentuk tanpa penambahan larutan garam seperti ion $\mathrm{Ca}^{2+}$. Kation divalen seperti $\mathrm{Ca}^{2+}$ dapat membentuk ikatan silang dengan blok glukoronat ( $\mathrm{G}$ ) yang ada dalam alginat (Lotfipour, Mirzaeei, \& Maghsoodi, 2012). Taha, Nasser, Ardakani, dan AlKhatib (2008); Lee dan Rogers (2013) melaporkan bahwa kombinasi alginat dangan larutan garam bivalen banyak digunakan dalam pembuatan mikroenkapsulasi. Vicini, Mauri, Wichert, dan Castellano (2017) juga menggunakan kation $\mathrm{Ca}^{2+}$ dalam pembuatan bulir alginat. Menurutnya, kekuatan ikatan silang ion divalent berturut-turut sebagai berikut: $\mathrm{Pb}^{2+}>\mathrm{Cu}^{2+}>\mathrm{Cd}^{2+}>\mathrm{Ba}^{2+}>\mathrm{Sr}^{2+}>\mathrm{Ca}^{2+}>\mathrm{Co}^{2+}, \mathrm{Ni}^{2+}, \mathrm{Zn}^{2+}>$ $\mathrm{Mn}^{2+}$. Pemilihan garam bivalen $\mathrm{Ca}^{2+}$ sebagai bahan enkapsulasi cairan $C$. racemosa dikarenakan ion $\mathrm{Ca}^{2+}$ lebih aman digunakan untuk produk pangan.

Dwiputra (2020) telah melakukan penelitian analog bulir $\mathrm{C}$. racemosa menggunakan konsentrasi $\mathrm{Na}$ alginat $(0,4 \% ; 0,6 \% ; 0,8 \% ; 1 \%)$ dan $\mathrm{CaCl}_{2}(0,5 \% ; 1 \%$; $1,5 \% ; 2 \%$ ) dengan pengenceran cairan $\mathrm{C}$. racemosa menggunakan air RO dengan hasil terbaik pada perlakuan kombinasi konsentrasi larutan $\mathrm{Na}$-alginat $0,6 \%$ dengan $\mathrm{CaCl}_{2}, 0,5 \%$ dan rasio cairan $C$. racemosa: air $\mathrm{RO}=1: 2,3$. Namun pada penelitian tersebut terdapat kelemahan, yakni kadar abunya masih tinggi, kadar serat rendah, serta timbulnya rasa pahit pada bulir dengan penggunaan $\mathrm{CaCl}_{2}$ yang berlebihan. Sementara itu, Peranginangin, Handayani, Fransiska, Marseno, dan Supriyadi (2015) juga menggunakan $\mathrm{Na}$-alginat dan $\mathrm{CaCl}_{2}$ pada pembuatan analog bulir jeruk, dengan perlakuan optimal pada kombinasi $\mathrm{Na}$-alginat $0,8 \%$ dan larutan $\mathrm{CaCl}_{2}$ 0,5\%. Oleh sebab itu, perlu dilakukan penelitian lebih lanjut mengenai kombinasi konsentrasi $\mathrm{Na}$-alginat dan $\mathrm{Ca}$ laktat yang dapat meningkatkan kadar serat dan menurunkan kadar abu bulir cairan $C$. racemosa. Penggunaan Ca-laktat juga tidak menimbulkan rasa pahit pada bulir cairan C. racemosa. Penelitian ini bertujuan untuk menentukan kombinasi konsentrasi $\mathrm{Na}$-alginat dan Ca-laktat terbaik dalam pembuatan bulir Caulerpa. Hasil penelitian ini diharapkan dapat mengoptimalkan pemanfaatan $C$. racemosa khususnya pada berbagai produk pangan.

\section{BAHAN DAN METODE}

\section{Bahan}

Bahan yang digunakan pada penelitian ini adalah rumput laut Caulerpa racemosa yang diperoleh dari perairan Binuangeun-Banten pada Bulan Mei 2019. Segera setelah dipanen, $C$. racemosa dibersihkan dan disortasi untuk menghilangkan kotoran, seperti karang, lumpur, dan jenis rumput laut lainnya. Tahapan penanganan selanjutnya adalah pencucian menggunakan air tawar hingga semua kotoran yang menempel bersih dengan indikasi air bekas cuciannya tidak kotor lagi. Bahan lain yang digunakan adalah natrium alginat food grade (teknis), kalsium laktat food grade (teknis), dan air RO (reverse osmosis). 


\section{Metode}

\section{Pembuatan bulir C. racemosa}

Pembuatan bulir $C$. racemosa mengacu pada metode yang dilakukan Dwiputra (2020) dengan modifikasi pada penggunaan Ca-laktat. C. racemosa yang telah bersih diekstrak cairannya menggunakan juice extractor (Philips HR1855). Cairan yang diperoleh ditambah air dengan perbandingan cairan $C$. racemosa dan air sebanyak 1:4 (v/v). Larutan $C$. racemosa ditambah $\mathrm{Na}$-alginat dengan variasi konsentrasi 0,$4 ; 0,6$; dan $0,8 \%(\mathrm{~b} / \mathrm{v})$ dari total volume larutan. Campuran dihomogenisasi menggunakan hand blender (Tokebi Lite) hingga Na-alginat terlarut sempurna. Selanjutnya campuran cairan Caulerpa dan $\mathrm{Na}$-alginat dimasukkan ke dalam larutan $\mathrm{Ca}$-laktat sehingga membentuk bulir Caulerpa. Larutan Ca-laktat disiapkan dengan melarutkannya dalam air dengan konsentrasi yang divariasi $(0,4 ; 0,6$; dan $0,8 \% \mathrm{~b} / \mathrm{v})$. Rasio larutan $\mathrm{Ca}$-laktat yang digunakan untuk membentuk bulir Caulerpa adalah rasio campuran cairan Caulerpa dan Na-alginat:Iarutan Ca-laktat yaitu $1: 2,5$.

\section{Karakterisasi C. racemosa dan bulir Caulerpa}

Pengamatan yang dilakukan terhadap rumput laut C. racemosa segar, cairan Caulerpa, dan campuran cairan Caulerpa dengan $\mathrm{Na}$-alginat adalah rendemen cairan Caulerpa, total padatan, kadar air (BSN, 2015), abu (BSN, 2010a), lemak (BSN, 2010b), protein (BSN, 2010c), kadar garam (BSN, 1991), serat pangan (AOAC, 2005), dan komposisi asam amino menggunakan Ultra Performance Liquid Chromatography/UPLC (Waters Acquity UPLC H Class) dengan kolom AccQ.Tag Ultra C18 1,7 $\mu \mathrm{m}$; 2,1X100 mm (Anon., 2012). Selanjutnya pengamatan terhadap bulir meliputi kadar air (BSN, 2015), abu (BSN, 2010a), dan serat kasar (AOAC, 2005).

\section{Analisis statistik}

Penelitian ini menggunakan Rancangan Acak Lengkap (RAL) faktorial dengan 2 faktor. Faktor pertama adalah konsentrasi $\mathrm{Na}$-alginat terdiri dari tiga taraf perlakuan $(0,4 ; 0,6 ;$ dan $0,8 \%)$, dan faktor kedua adalah kosentrasi kalsium laktat dengan tiga taraf perlakuan $(0,4 ; 0,6$; dan $0,8 \%)$. Perlakuan dalam penelitian ini masing-masing dilakukan dalam tiga kali ulangan. Data yang diperoleh dianalisis menggunakan ANOVA dengan uji lanjut Duncan pada perangkat lunak SPSS Ver. 17.

\section{HASIL DAN PEMBAHASAN}

\section{Karakteristik C. racemosa Segar dan Cairan C. racemosa}

Hasil karakterisasi C. racemosa segar, cairan Caulerpa, dan campuran cairan Caulerpa-alginat dapat dilihat pada Tabel 1. Campuran cairan Caulerpa-air adalah cairan Caulerpa yang telah mengalami pengenceran dengan perbandingan Caulerpa dan air sebesar 1:4 (v/v). Rendemen cairan Caulerpa yang dihasilkan menggunakan juice extractor sebesar $91,21 \pm 1,92 \%$ dari C. racemosa segar, sehingga diperoleh ampas sebesar $8,79 \%$. C. racemosa segar mengandung kadar air yang sangat tinggi, mencapai $96,03 \pm 0,79 \%$. Nilai ini lebih tinggi dibandingkan hasil penelitian de Gaillande et al. (2017), yang melaporkan bahwa kadar air $C$. rasemosayang berasal dari daerah Indo-Pasifik berkisar antara 88,8-91,5\%. Adanya perbedaan ini diduga dipengaruhi oleh faktor lingkungan yang berbeda. Sementara itu, kadar air campuran cairan Caulerpa dengan air juga memiliki

Tabel 1. Karakteristik C. racemosa segar dan cairan C. racemosa Table 1. Characteristics of fresh C. racemosa and C. racemosa liquid

\begin{tabular}{lccc}
\hline \multicolumn{1}{c}{ Parameter/Parameters } & $\begin{array}{c}\text { C. racemosa } \\
\text { segar/Fresh } \\
\text { C. racemosa }\end{array}$ & $\begin{array}{c}\text { Cairan } \\
\text { Caulerpa/ } \\
\text { Caulerpa } \\
\text { liquid }\end{array}$ & $\begin{array}{c}\text { Campuran cairan } \\
\text { Caulerpa-air (1:4 v/v)/ } \\
\text { Mixture of Caulerpa } \\
\text { liquid-water (1:4 v/v) }\end{array}$ \\
\hline Rendemen/Yield (\%) & 100 & $91.21 \pm 1.92$ & 100 \\
Padatan/Solid $(\%)$ & $3.97 \pm 0.56$ & $2.01 \pm 0.97$ & $0.39 \pm 0.25$ \\
Kadar air/Moisture content (\%) & $96.03 \pm 0.79$ & $97.77 \pm 0.02$ & $99.60 \pm 0.61$ \\
Kadar abu/Ash content $(\%)$ & $2.98 \pm 0.09$ & $0.62 \pm 0.03$ & $0.12 \pm 0.66$ \\
Kadar lemak/Fat content $(\%)$ & $0.14 \pm 0.02$ & $0.15 \pm 0.04$ & $0.03 \pm 0.73$ \\
Kadar protein/Protein content (\%) & $0.35 \pm 0.11$ & $0.15 \pm 0.02$ & $0.03 \pm 0.21$ \\
Kadar garam/Salt content (\%) & $1.57 \pm 0.43$ & $0.09 \pm 0.04$ & $0.02 \pm 0.32$ \\
Serat pangan/Dietary fiber content (\%) & $5.04 \pm 0.01$ & $1.51 \pm 0.08$ & $0.03 \pm 0.34$ \\
\hline
\end{tabular}


nilai yang lebih tinggi dibandingkan cairan $C$. racemosa, disebabkan adanya pengenceran pada cairan Caulerpa. Hal ini diperkuat dengan nilai total padatan pada campuran cairan Caulerpa dengan air memiliki nilai yang lebih rendah dibandingkan cairan Caulerpa, sehingga kadar airnya menjadi lebih tinggi.

C. racemosa segar mengandung kadar abu $2,98 \pm 0,09 \%$, sedangkan kadar abu dalam cairan Caulerpa 0,62 $\pm 0,03 \%$. Nilai kadar abu tersebut berasal dari garam dan mineral yang terkandung dalam rumput laut. Unsur mineral makro dan mikro yang terdapat dalam rumput laut $C$. racemosa meliputi $\mathrm{Na}, \mathrm{K}, \mathrm{Ca}$, $\mathrm{Mg}, \mathrm{Fe}, \mathrm{Zn}, \mathrm{Mn}, \mathrm{Cu}$, Se, dan Mo (de Gaillande et al., 2017; Ratana-arporn \& Chirapart, 2006; Tapotubun, 2018). Kadar garam yang merupakan salah satu komponen dalam kadar abu ditemukan sebesar $1,57 \pm 0,43 \%$ dalam Caulerpasegar, sedangkan dalam cairan $C$. racemosa sebesar $0,09 \pm 0,04 \%$. Hal ini menunjukkan bahwa proses pencucian $C$. racemosa dapat mereduksi kadar garam sebesar $94,3 \%$.

Hasil analisa kadar lemak Caulerpa segar (3,53\% BK) memiliki nilai yang lebih tinggi dibanding $C$. racemosa $(2,64 \% \mathrm{BK})$ yang dilaporkan oleh Kumar, Gupta, Kumari, Reddy, dan Jha (2011), tetapi lebih rendah dibanding $C$. racemosa asal Hawaii $(7,2 \% \mathrm{BK})$ hasil penelitian McDermid dan Stuercke (2003). Sementara itu, untuk kadar protein, Caulerpa segar $(8,82 \% \mathrm{BK})$ memiliki nilai yang lebih rendah dibanding hasil penelitian Kumar et al., (2011) yang sebesar $12,88 \%$ BK, tetapi lebih tinggi dibanding $C$. racemosa asal Vietnam, yaitu 5,8\% BK (Hong, Hien, \& Son,
2007). Kadar protein C. racemosa segar memiliki nilai yang lebih tinggi dibanding cairan yang diperoleh. Hal ini diduga karena protein sebagian besar terkandung dalam ampas rumput laut atau karena faktor pengenceran. Cairan $C$. racemosa masih mengandung protein, yang terdiri atas asam amino esensial dan non esensial dengan komposisi seperti yang terlihat pada Tabel 2. Asam amino non esensial tertinggi adalah asam glutamat $(12,45 \%)$, sementara asam amino esensial tertinggi pada cairan $C$. racemosa adalah leusin $(9,28 \%)$. Magdugo et al. (2020) juga melaporkan bahwa asam glutamat dan leusin merupakan jenis asam amino tertinggi dalam $C$. racemosa, berturut-turut sebesar $18,70 \%$ dan $9,64 \%$.

\section{Pembentukan Bulir Caulerpa}

Cairan C. rasemosa yang sudah ditambah $\mathrm{Na}$ alginat dan diteteskan ke dalam larutan Ca-laktat mempunyai bentuk fisik bulat sedikit agak lonjong, berwarna hijau, bau spesifik $C$. racemosa, agak kenyal, dan berdiameter 2-4 mm dengan berat bulir sekitar 1,5 g/10 butir bulir (Gambar 1). Larutan Naalginat mengandung poliguluronat, ketika diteteskan ke larutan kation $\mathrm{Ca}^{2+}$ maka akan bereaksi membentuk ikatan silang egg box (Fu et al., 2011). Semakin tinggi rasio guluronat : manuronat maka semakin kuat ikatan silang yang terjadi. Reaksi Naalginat dengan kation $\mathrm{Ca}^{2+}$ akan berjalan lambat atau bertahap, hingga semua kation $\mathrm{Ca}^{2+}$ bereaksi membentuk Ca-alginat.

Tabel 2. Komposisi asam amino dalam cairan $C$. racemosa

Table 2. Amino acid composition in $\underline{\text { C. racemosa liquid }}$

\begin{tabular}{clc}
\hline & \multicolumn{1}{c}{ Asam amino/Amino acids } & Komposisi/Composition (\%) \\
\hline & Treonin/Threonine & $7.54 \pm 0.19$ \\
& Valin/Valine & $6.87 \pm 0.23$ \\
Asam amino & Lisin/Lysine & $4.19 \pm 2.02$ \\
esensial/Essential Amino & Isoleusin/Isoleucine & $5.14 \pm 0.14$ \\
Acids (EAAs) & Leusin/Leucine & $9.28 \pm 0.48$ \\
& Fenilalanin/Phenylalanine & $6.32 \pm 0.28$ \\
& Histidin/Histidine & $1.97 \pm 2.49$ \\
\hline & Asam aspartat/Aspartic acid & $9.82 \pm 1.48$ \\
& Serin/Serine & $7.30 \pm 0.55$ \\
Asam amino non & Asam glutamat/Glutamic acid & $12.45 \pm 1.93$ \\
Amino Acids (NEAAs) & Glisin/Glycine & $6.83 \pm 0.43$ \\
& Alanin/Alanine & $7.02 \pm 0.31$ \\
& Tirosin/Tyrosine & $4.05 \pm 0.74$ \\
& Prolin/Proline & $4.34 \pm 0.53$ \\
& Arginin/Arginine & $5.89 \pm 2.41$ \\
\hline
\end{tabular}




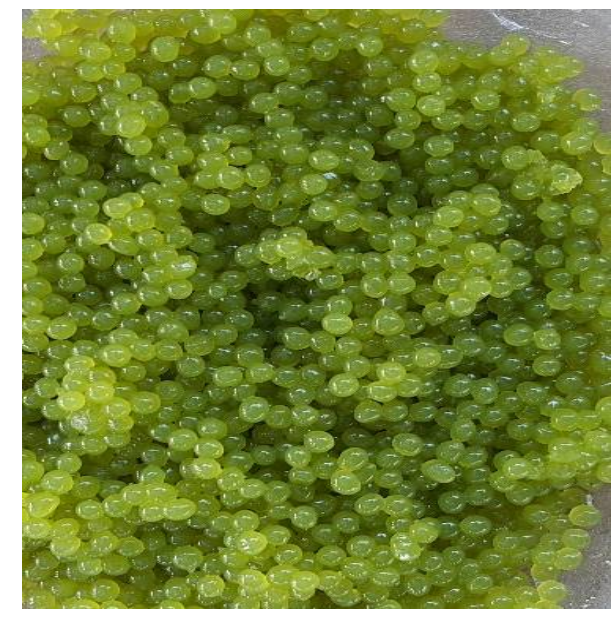

Gambar 1. Bulir cairan C. racemosa

Figure 1. $\underline{\text { C. }}$ racemosa liquid grain

Reaksi antara Na-alginat dengan Ca-laktat dalam membentuk lapisan pelindung pada cairan $C$. racemosa dipengaruhi oleh konsentrasi yang diberikan. $\mathrm{Na}$-alginat adalah biopolimer larut air dan membentuk struktur gel dengan adanya kation divalen seperti $\mathrm{Ca}$ dan $\mathrm{Zn}$. Penggantian kation $\mathrm{Na}^{+}$dengan $\mathrm{Ca}^{2+}$ di atas $35 \%$ akan menghentikan pergeseran molekul dan membentuk struktur gel yang stabil dan tidak larut dalam air dingin maupun air panas (Fu et al., 2011). Pada saat terjadi pembentukan gel alginat, cairan Caulerpa terperangkap dalam $\mathrm{Ca}$-alginat sehingga menghasilkan bulir yang menyerupai ramuli pada rumput laut $C$. racemosa. Kalsium alginat yang terbentuk pada lapisan luar bulir Caulerpa akan melindungi cairan Caulerpa di dalam bulir sehingga tidak terdifusi ke luar bulir.

\section{Kualitas Bulir}

\section{Kadar air bulir Caulerpa}

Kadar air bulir cairan $C$. racemosa berkisar antara $96,61-97,79 \%$ (Gambar 2). Analisis menunjukkan bahwa kadar air bulir dipengaruhi oleh perlakuan konsentrasi Ca-laktat $(p<0,05)$, namun tidak dipengaruhi oleh perlakuan konsentrasi $\mathrm{Na}$-alginat dan interaksi antar keduanya $(p>0,05)$. Kadar air bulir dengan perlakuan $\mathrm{Na}$-alginat $0,8 \%$ dan $\mathrm{Ca}$-laktat $0,8 \%$ tidak berbeda nyata dengan perlakuan $\mathrm{Na}$-alginat $0,4 \%$

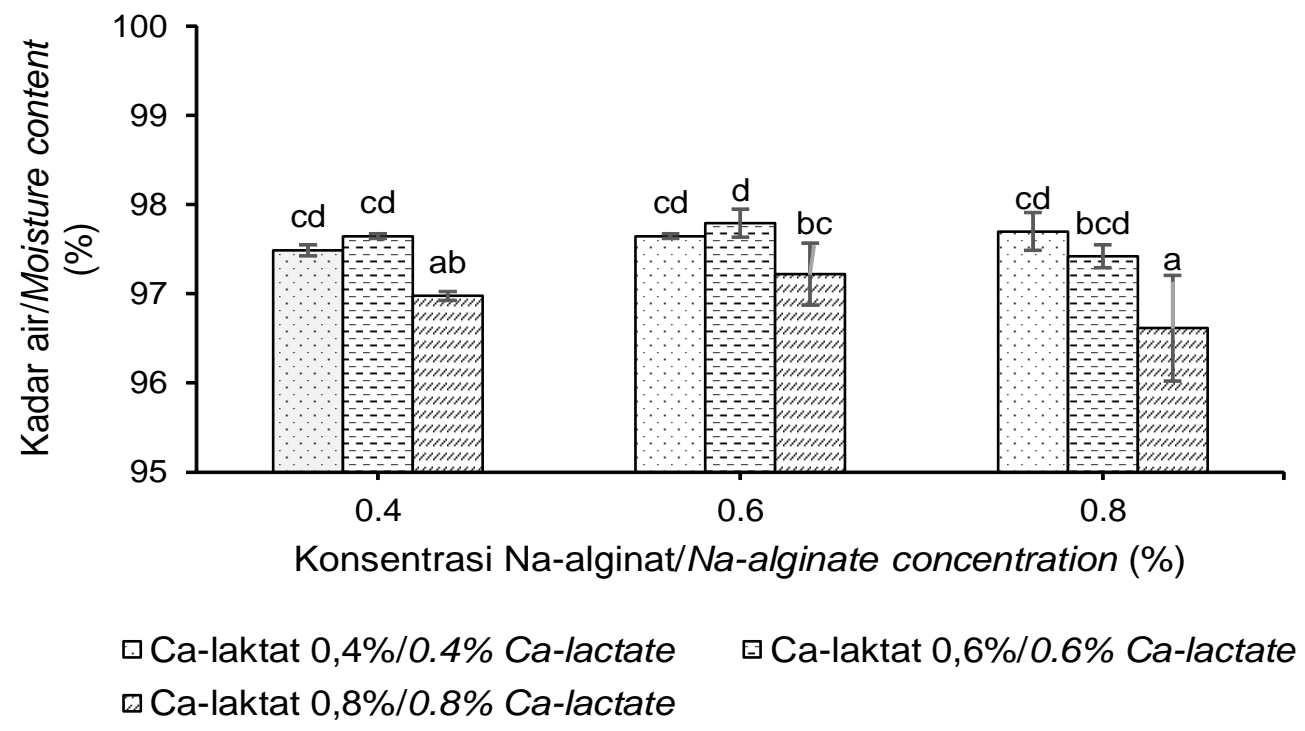

Gambar 2. Kadar air bulir C. racemosa

Figure 2. Moisture content of $\underline{\text { C. racemosa liquid grain }}$ 
dan Ca-laktat 0,8\%; namun berbeda nyata dengan perlakuan lainnya. Nilai kadar air terendah diperoleh pada perlakuan konsentrasi $\mathrm{Na}$-alginat $0,8 \%$ dan $\mathrm{Ca}$ laktat $0,8 \%$, yaitu sebesar $96,61 \%$, dan tertinggi pada perlakuan konsentrasi $\mathrm{Na}$-alginat $0,6 \%$ dan $\mathrm{Ca}$-laktat $0,6 \%$, yaitu sebesar $97,79 \%$. Semakin tinggi konsentrasi $\mathrm{Na}$-alginat yang diberikan menyebabkan sejumlah air yang ada dalam cairan $C$. racemosa semakin terikat kuat, sebaliknya semakin rendah konsentrasi $\mathrm{Na}$-alginat maka ikatan silang semakin lemah.

Hasil penelitian menunjukkan peningkatan konsentrasi larutan $\mathrm{Na}$-alginat dan Ca-laktat menyebabkan terjadinya sineresis/kehilangan sejumlah air yang lebih tinggi dibandingkan dengan penggunaan konsentrasi $\mathrm{Na}$-alginat dan $\mathrm{Ca}$-laktat yang lebih rendah dalam pembentukan $\mathrm{Ca}$-alginat pada lapisan luar bulir cairan C. racemosa (Gambar 2). Sineresis ini diduga karena banyaknya ion $\mathrm{Na}^{+}$ yang tersubstitusi oleh ion $\mathrm{Ca}^{2+}$, sehingga menyebabkan sejumlah air keluar dari bulir Caulerpa. Hal ini sesuai dengan hasil penelitian Velings dan Mestdagh (1995) yang melaporkan bahwa proses sineresis atau kehilangan air dari bulir Caulerpa akan terjadi secara simultan tergantung pada konsentrasi $\mathrm{Na}$-alginat dan kation $\mathrm{Ca}^{2+}$ yang bereaksi membentuk Ca-alginat.

\section{Kadar abu}

Kadar abu merupakan campuran dari komponen anorganik atau mineral yang terdapat dalam bahan pangan (de Gaillande et al., 2017; Purwaningsih, 2012; Ratana-arporn \& Chirapart, 2006; Tapotubun, 2018).
Kadar abu dapat dijadikan sebagai petunjuk keberadaan mineral suatu bahan. Bahan makanan umumnya terdiri atas $96 \%$ zat organik dan air, sedangkan sisanya terdiri atas unsur mineral atau zat anorganik (Winarno, 2008). Hasil analisis kadar abu bulir Caulerpa berkisar antara 0,49-0,71\%. Pada penelitian ini, perlakuan variasi konsentrasi $\mathrm{Na}$-alginat pada konsentrasi Ca-laktat yang sama, menghasilkan kadar abu yang sebanding (Gambar 3). Hasil perlakuan variasi konsentrasi Ca-laktat dengan konsentrasi $\mathrm{Na}$-alginat yang sama, menunjukkan adanya peningkatan kadar abu seiring peningkatan konsentrasi Ca-laktat. Hal ini sesuai dengan hasil analisis ANOVA, yaitu nilai kadar abu bulir dipengaruhi oleh perlakuan konsentrasi Ca-laktat $(p<0,05)$, namun tidak dipengaruhi oleh perlakuan konsentrasi $\mathrm{Na}$ alginat dan interaksi antar keduanya $(p>0,05)$. Kadar abu bulir dengan perlakuan Ca-laktat $0,8 \%$ tidak berbeda nyata pada ketiga variasi konsentrasi $\mathrm{Na}$ alginat, namun berbeda nyata dengan perlakuan lainnya.

Nilai kadar abu terendah diperoleh pada perlakuan konsentrasi $\mathrm{Na}$-alginat $0,8 \%$ dan Ca-laktat $0,4 \%$ yaitu sebesar $0,49 \pm 0,08 \%$, sedangkan nilai tertinggi diperoleh pada perlakuan $\mathrm{Na}$-alginat $0,4 \%$ dan $\mathrm{Ca}-$ laktat $0,8 \%$; yaitu sebesar $0,71 \pm 0,03 \%$. Rendahnya kadar abu pada penelitian ini dikarenakan terjadinya pelepasan mineral atau bahan organik dari bulir Caulerpa akibat adanya perlakuan suhu panas $\left(80^{\circ} \mathrm{C}\right)$. Sipayung, Suparmi, dan Dahlia (2015) menyatakan bahwa komponen abu suatu bahan mudah mengalami dekomposisi atau berkurang akibat adanya perlakuan perebusan yang dapat menurunkan kadar abu yang

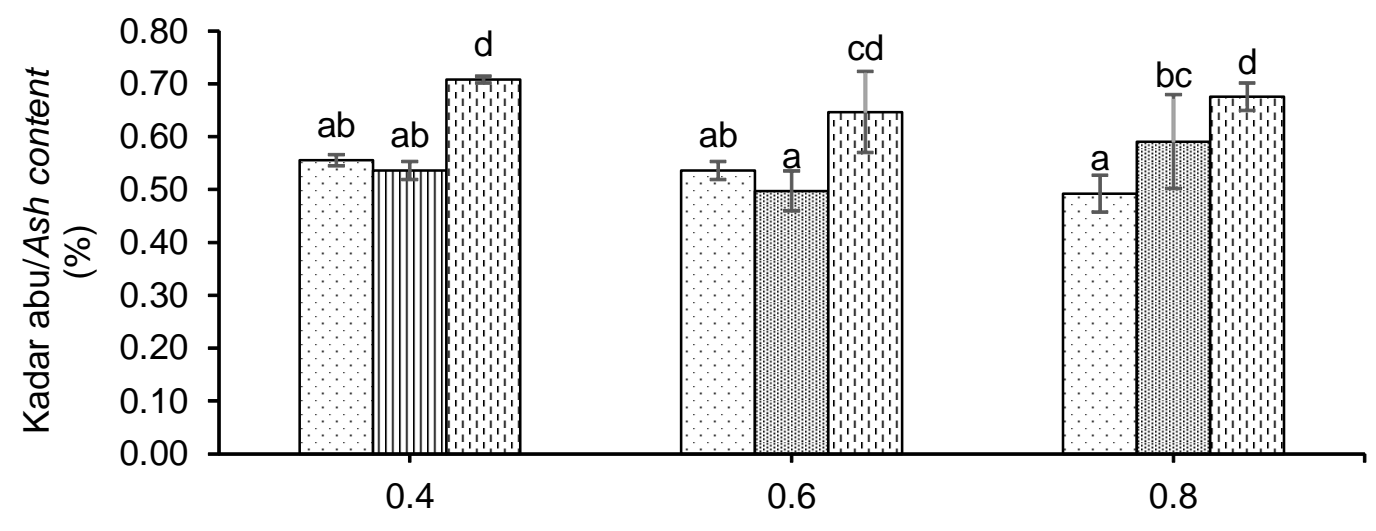

Konsentrasi $\mathrm{Na}$-alginat/Na-alginate concentration (\%)

口Ca-laktat 0.4\%/0.4\% Ca-lactate $\quad$ DCa-laktat $0.6 \% / 0.6 \%$ Ca-lactate

口Ca-laktat $0.8 \% / 0.8 \%$ Ca-lactate

Gambar 3. Kadar abu bulir $C$. racemosa

Figure 3. Ash content of $\underline{C}$. racemosa liquid grain 
dihasilkan. Kadar abu yang diperoleh pada penelitian ini dapat digunakan sebagai pencerminan berat kering bulir Caulerpa.

Secara keseluruhan terdapat peningkatan kadar abu pada semua perlakuan dibandingkan dengan kadar abu pada cairan Caulerpa (Tabel 1). Peningkatan kadar abu tersebut diakibatkan adanya reaksi antara $\mathrm{Na}$-alginat dengan $\mathrm{Ca}$-laktat membentuk $\mathrm{Ca}$-alginat yang tidak larut air. Kation $\mathrm{Ca}^{2+}$ merupakan mineral yang akan membentuk egg box dan mempengaruhi nilai kadar abu (Fu et al., 2011). Menurut Maharani, Husni, \& Ekantari (2017), kadar abu Na-alginat komersial sebesar $19,76 \%$. Adanya sumbangan mineral dari Ca-laktat telah menyebabkan kadar abu bulir Caulerpa meningkat dibandingkan dengan kadar abu cairan Caulerpa (0,62\%).

\section{Kadar serat kasar}

Kadar serat kasar bulir Caulerpa berkisar antara 1,96-4,05\% (Gambar 4). Hasil uji statistik kadar serat kasar bulir tidak dipengaruhi oleh perlakuan perbedaan konsentrasi Ca-laktat $(p>0,05)$, namun dipengaruhi oleh perlakuan perbedaan konsentrasi $\mathrm{Na}$-alginat dan interaksi antar keduanya $(p<0,05)$. Kadar serat kasar bulir dengan perlakuan $\mathrm{Na}$-alginat $0,4 \%$ dan $\mathrm{Ca}$-laktat $0,6 \%$ tidak berbeda nyata dengan perlakuan $\mathrm{Na}$-alginat $0,6 \%$ dan Ca-laktat $0,8 \%$, namun berbeda nyata dengan perlakuan lainnya. Nilai serat kasar terendah diperoleh pada perlakuan konsentrasi $\mathrm{Na}$-alginat $0,8 \%$ dan Ca-laktat $0,8 \%$; yaitu sebesar $1,85 \pm 0,90 \%$, sedangkan nilai tertinggi diperoleh pada perlakuan $\mathrm{Na}-$ alginat $0,6 \%$ dan Ca-laktat $0,8 \%$; yaitu sebesar $4,05 \pm 0,43 \%$. Pada Tabel 1 terlihat bahwa kadar serat cairan C. racemosa sebesar $1,51 \%$. Setelah direaksikan dengan kombinasi perlakuan $\mathrm{Na}$-alginat dan Ca-laktat, semua perlakuan mengalami peningkatan kadar serat kasar. Hasil perhitungan menunjukkan bahwa penambahan serat dari cairan C. racemosa ke dalam bulir Caulerpa berkisar antara 23-168\%. Penambahan serat kasar terendah pada perlakuan kombinasi $\mathrm{Na}$-alginat $0,8 \%$ dan $\mathrm{Ca}$-laktat $0,8 \%$, sebesar $23 \%$. Sementara penambahan tertinggi diperoleh pada perlakuan kombinasi $\mathrm{Na}$-alginat $0,6 \%$ dan Ca-laktat 0,8\%; yaitu sebesar $168 \%$.

Berdasarkan penelitian ini, diketahui bahwa semakin banyak alginat yang bereaksi dengan ion $\mathrm{Ca}^{2+}$, semakin tinggi kadar serat kasar dalam bulir $C$. racemosa. Alginat adalah polimer linier organik polisakarida yang terdiri dari monomer $\alpha-L$ asam guluronat $(\mathrm{G})$ dan $\beta-D$ asam manuronat $(M)$, atau dapat berupa kombinasi dari kedua monomer tersebut yang dikelompokkan dalam bentuk serat komplek (Rowe, Sheskey, \& Quinn, 2009). Asam alginat dapat bereaksi dengan garam mono maupun bivalen. Dalam penelitian ini telah digunakan kation $\mathrm{Na}^{+}$yang membentuk $\mathrm{Na}$-alginat yang kemudian disubstitusikan dengan kation $\mathrm{Ca}^{2+}$. Pembentukan ikatan silang egg box pada reaksi ini akan mencapai kesetimbangan dengan jumlah Na yang lebih banyak. Dua gugus $\mathrm{Na}-$ alginat akan mengikat satu ion $\mathrm{Ca}^{2+}$, sebagai akibatnya jumlah alginat yang terikat pada ion $\mathrm{Ca}^{2+}$ lebih banyak. Peningkatan jumlah alginat dalam cairan bulir $C$. racemosa menjadi $\mathrm{Ca}$-alginat sebagai pelindung cairan $C$. racemosa menyebabkan kandungan serat kasarnya meningkat. Selain berasal dari alginat yang terikat dengan $\mathrm{Ca}^{2+}$ membentuk $\mathrm{Ca}$ -

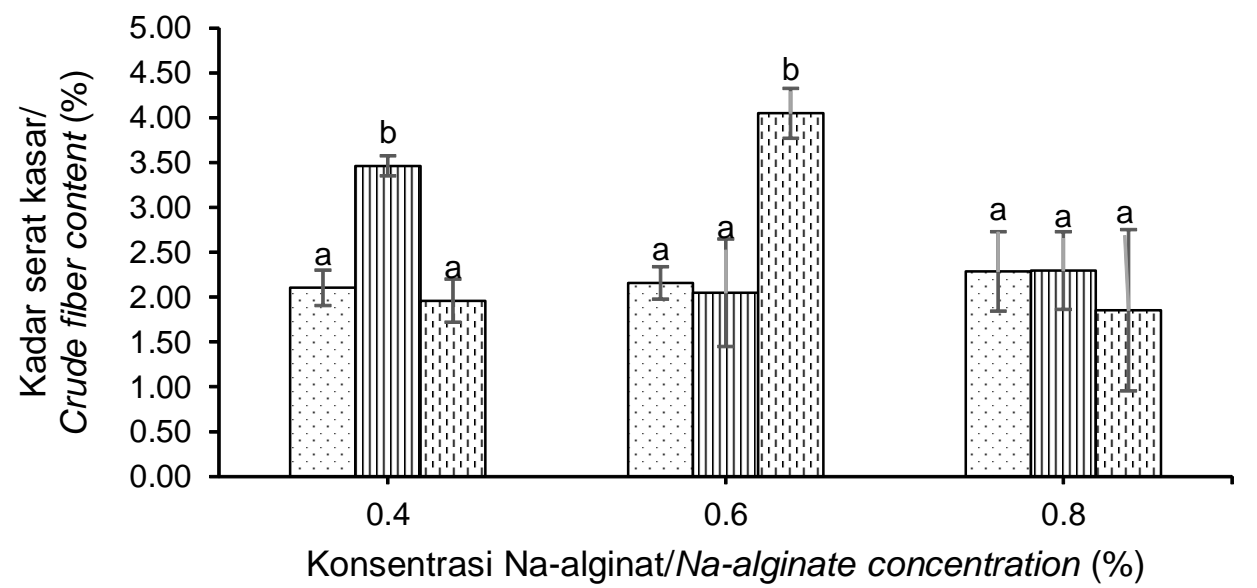

$\square$ Ca-laktat $0.4 \% / 0.4 \%$ Ca-lactate

m Ca-laktat $0.6 \% / 0.6 \%$ Ca-lactate

(1) Ca-laktat $0.8 \% / 0.8 \%$ Ca-lactate

Gambar 4. Kadar serat kasar bulir C. racemosa

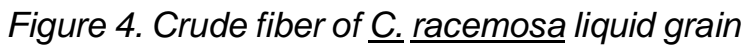


alginat, peningkatan kadar serat kasar juga dipengaruhi oleh campuran $\mathrm{Na}$-alginat dengan cairan $\mathrm{C}$. racemosa yang tidak bereaksi dengan Ca-laktat.

\section{KESIMPULAN}

Cairan $C$. racemosa mengandung serat pangan dan asam amino baik esensial maupun non esensial, sehingga dapat diolah menjadi produk pangan bernutrisi. Kadar air cairan $C$. racemosa sebesar $97,77 \pm 0,02 \%$ dan setelah ditambah air dengan rasio $1: 4$, kadar air cairan $C$. racemosa menjadi $99,6 \pm 0,61 \%$. Cairan C. racemosa dapat dibentuk menjadi bulir dengan menambahkan $\mathrm{Na}$-alginat yang direaksikan dengan larutan Ca-laktat membentuk lapisan tipis di permukaan bulir cairan $C$. racemosa. Perlakuan konsentrasi Ca-laktat berpengaruh terhadap kadar air dan kadar abu bulir yang dihasilkan, sementara kadar serat kasar bulir dipengaruhi oleh perbedaan konsentrasi $\mathrm{Na}$-alginat. Nilai terbaik berdasarkan kadar serat ditemukan pada perlakuan kombinasi $\mathrm{Na}$-alginat $0,6 \%$ dan Ca-laktat $0,8 \%$; yaitu sebesar $4,05 \%$ dengan kadar air $97,22 \%$ serta kadar abu $0,65 \%$.

\section{DAFTAR PUSTAKA}

Anonymous (Anon). (2012). Waters acquity UPLC H class and $H$ class bio amino acid analysis system guide. USA.

Association of Official Analytical Chemists (AOAC). (2005). Official method of analysis of the association of official analitycal chemists. 18th ed. Maryland: AOAC International. William Harwitz (ed). United States of America.

Aristya, I. M. T. W., Admadi, B., \& Arnata, I. W. (2017). Karakteristi mutu dan rendemen alginat dari ekstrak rumput laut Sargassum sp. dengan menggunakan larutan asam asetat. Jurnal Rekayasa Dan Manajemen Agroindustri, 5(1), 81-92.

Badan Standardisasi Nasional (BSN). (1991). SNI $01-$ 2359-1991 Produk perikanan, penentuan kadar garam. Jakarta: Badan Standardisasi Nasional.

Badan Standardisasi Nasional (BSN). (2010a). SNI 2354.1-2010 Cara uji kimia - Bagian 1: Penentuan kadar abu dan abu tak larut asam pada produk perikanan. Jakarta: Badan Standardisasi Nasional.

Badan Standardisasi Nasional (BSN). (2010b). SNI 2354.3-2010 Cara uji kimia - Bagian 3: Penentuan kadar lemak total pada produk perikanan. Jakarta: Badan Standardisasi Nasional.

Badan Standardisasi Nasional (BSN). (2010c). SNI 2354.4-2010 Cara uji kimia - Bagian 4: Penentuan kadar protein dengan metode total nitrogen pada produk perikanan. Jakarta: Badan Standardisasi Nasional.

Badan Standardisasi Nasional (BSN). (2015). SNI 2354.2-2015 Cara uji kimia- Bagian 2: Penentuan kadar air pada produk perikanan. Jakarta: Badan Standardisasi Nasional.

de Gaillande, C., Payri, C., Remoissenet, G., \& Zubia, M. (2017). Caulerpa consumption, nutritional value and farming in the Indo-Pacific region. Journal of Applied Phycology, 29(5), 2249-2266. doi: 10.1007/s10811016-0912-6

Dwiputra, R. R. (2020). Pembuatan analog bulir Caulerpa racemosa sebagai produk tambahan pada minuman kemasan. Skripsi. Bogor (ID): Departemen Teknologi Hasil Perairan Fakultas Perikanan dan Kelautan Institut Pertanian Bogor.

Fu, S., Thacker, A., Sperger, D. M., Boni, R. L., Buckner, I. S., Velankar, S., ... Block, L. H. (2011). Relevance of rheological properties of sodium alginate in solution to calcium alginate gel properties. AAPS PharmSciTech, 12(2), 453-460. doi: 10.1208/s12249011-9587-0

Hong, D. D., Hien, H. M., \& Son, P. N. (2007). Seaweeds from Vietnam used for functional food, medicine and biofertilizer. Journal of Applied Phycology, 19(6), 817-826. doi: 10.1007/s10811-007-9228-x

Kasim, S., Marzuki, A., \& Sudir, S. (2017). Effects of sodium carbonate concentration and temperature on the yield and quality characteristics of alginate extracted from Sargassum sp. Research Journal of Pharmaceutical, Biological and Chemical Sciences, 8(1), 660-668.

Khan, H., Athar, M., Viqar, S., \& Ara, J. (2012). Evaluation of biochemical component and antimicrobial activity of some seaweeeds occurring at Karachi coast. Pakistan Journal of Botany, 44(5), 1799-1803.

Kumar, M., Gupta, V., Kumari, P., Reddy, C. R. K., \& Jha, B. (2011). Assessment of nutrient composition and antioxidant potential of Caulerpaceae seaweeds. Journal of Food Composition and Analysis, 24(2), 270-278. doi: 10.1016/j.jfca.2010.07.007

Lee, P., \& Rogers, M. A. (2013). Effect of calcium source and exposure-time on basic caviar spheri fi cation using sodium alginate. International Journal of Gastronomy and Food Science, 1(2), 96-100. doi: 10.1016/j.ijgfs.2013.06.003

Lotfipour, F., Mirzaeei, S., \& Maghsoodi, M. (2012). Evaluation of the effect of $\mathrm{cacl} 2$ and alginate concentrations and hardening time on the characteristics of Lactobacillus acidophilus loaded alginate beads using response surface analysis. Advanced Pharmaceutical Bulletin, 2(1), 71-78. doi: 10.5681/apb.2012.010

Mabeau, S., \& Fleurence, J. (1993). Seaweed in food products: biochemical and nutritional aspects. Trends in Food Science and Technology, 4(4), 103-107. doi: 10.1016/0924-2244(93)90091-N

Magdugo, R. P., Terme, N., Lang, M., Pliego-cort, H., Marty, C., Hurtado, A. Q., ... Bourgougnon, N. (2020). An analysis of the nutritional and health values of Caulerpa racemosa (Forsskal) and Ulva fasciata (Delile)-two chlorophyta collected from the Philippines. Molecules, 25, 1-23. doi: 10.3390/ molecules25122901 
Maharani, A. A., Husni, A., \& Ekantari, N. (2017). Karakteristik natrium alginat rumput laut cokelat Sargassum fluitans dengan metode ekstraksi yang berbeda. Jurnal Pengolahan Hasil Perikanan Indonesia, 20(3), 478-487.

Matanjun, P., Mohamed, S., Mustapha, N. M., \& Muhammad, K. (2009). Nutrient content of tropical edible seaweeds, Eucheuma cottonii, Caulerpa lentillifera and Sargassum polycystum. Journal of Applied Phycology, 21(1), 75-80. doi: 10.1007/ s10811-008-9326-4

McDermid, K. J., \& Stuercke, B. (2003). Nutritional composition of edible Hawaiian seaweeds. Journal of Applied Phycology, 15(6), 513-524. doi: 10.1023/ B:JAPH.0000004345.31686.7f

Mushollaeni, W., \& Rusdiana, E. (2011). Characterization of sodium alginate from Sargassum sp., Turbinaria sp. and Padina sp. Jurnal Teknologi Dan Industri Pangan, XXII(1), 26-32.

Ortiz, J., Romero, N., Robert, P., Araya, J., LopezHernández, J., Bozzo, C., ... Rios, A. (2006). Dietary fiber, amino acid, fatty acid and tocopherol contents of the edible seaweeds Ulva lactuca and Durvillaea antarctica. Food Chemistry, 99(1), 98-104. doi: 10.1016/j.foodchem.2005.07.027

Pamungkas, T. A., Ridlo, A., \& Sunaryo. (2013). Pengaruh suhu ekstraksi terhadap kualitas natrium alginat rumput laut Sargassum sp. Journal of Marine Research, 2(3), 78-84. doi: 10.14710/jmr.v2i3.3135

Peranginangin, R., Handayani, A. M., Fransiska, D., Marseno, D. W., \& Supriyadi. (2015). Pengaruh konsentrasi $\mathrm{CaCl} 2$ dan alginat terhadap karakteristik analog bulir jeruk dari alginat. Jurnal Pascapanen dan Bioteknologi Kelautan Dan Perikanan, 10(2), 163-172. doi: 10.15578/jpbkp.v10i2.375

Purwaningsih, S. (2012). Aktivitas antioksidan dan komposisi kimia keong matah merah (Cerithidea obtusa). Ilmu Kelautan, 17(1), 39-48.

Ratana-arporn, P., \& Chirapart, A. (2006). Nutritional evaluation of tropical green seaweeds Caulerpa lentillifera and Ulva reticulata. Kasetsart Journal (Natural Science), 40, 75-83.

Rowe, R. C., Sheskey, P. J., \& Quinn, M. E. (2009). Handbook of Pharmaceutical Excipients. Sixth Edition. In Pharmaceutical Press. Washington DC.

Sánchez-Machado, D. I., López-Cervantes, J., LópezHernández, J., \& Paseiro-Losada, P. (2004). Fatty acids, total lipid, protein and ash contents of processed edible seaweeds. Food Chemistry, 85(3), 439-444. doi: 10.1016/j.foodchem.2003.08.001

Santoso, J., Yoshie-Stark, Y., \& Suzuki, T. (2004). Antioxidant activity of methanol extracts from Indonesian seaweeds in an oil emulsion model. Fisheries Science, 70(1), 183-188. doi: 10.1111/j.14442906.2003.00787.x

Santoso, J., Yoshie, Y., \& Suzuki, T. (2002). The distribution and profile of nutrients and catechins of some Indonesian seaweeds. Fisheries Science, 68, 16471648. doi: 10.2331/fishsci.68.sup2_1647

Sipayung, M. Y., Suparmi, \& Dahlia. (2015). Pengaruh suhu pengukusan terhadap sifat fisika kimia tepung ikan rucah. Jurnal Pengolahan UNRI, 2(1), 1-13.

Subaryono. (2010). Modifikasi alginat dan pemanfaatan produknya. Squalen Bulletin of Marine and Fisheries Postharvest and Biotechnology, 5(1), 1-7.

Sukma, I. W. A., Harsojuwono, B. A., \& Arnata, I. W. (2017). Pengaruh suhu dan lama pemanasan ekstraksi terhadap rendemen dan mutu alginat dari rumput laut hijau Sargassum sp. Jurnal Rekayasa Dan Manajemen Agroindustri, 5(1), 71-80.

Taha, M. O., Nasser, W., Ardakani, A., \& AlKhatib, H. S. (2008). Sodium lauryl sulfate impedes drug release from zinc-crosslinked alginate beads: switching from enteric coating release into biphasic profiles. International Journal of Pharmaceutics, 350(1), 291 300. doi: 10.1016/j.jpharm.2007.09.010

Tamat, S. R., Wikanta, T., \& Maulina, L. S. (2007). Aktivitas Antioksidam dan toksisitas senyawa bioaktif dari ekstrak rumput laut hijau Ulva reticulata Forsskal. Jurnal IImu Kefarmasian Indonesia, 5(1), 31-36.

Tapotubun, A. M. (2018). Komposisi kimia rumput laut (Caulerpa lentillifera) dari Perairan Kei Maluku dengan metode pengeringan berbeda. Jurnal Pengolahan Hasil Perikanan Indonesia, 21(1), 1323. doi: 10.17844/jphpi.v21i1.21257

Utomo, B. S. B., Marraskuranto, E., Basmal, J., Murdinah, Kusumawati, R., Tazwir, \& Wikanta, T. (2014). Membuat alginat dari rumput laut Sargassum. Penebar Swadaya.

Velings, N. M., \& Mestdagh, M. M. (1995). PhysicoChemical properties of alginate gel beads. Polymer Gels and Networks, 3, 311--330.

Vicini, S., Mauri, M., Wichert, J., \& Castellano, M. (2017). Alginate gelling process : use of bivalent ions rich microspheres. Polimer Engineering and Science, 57(6), 1-6. https://doi.org/10.1002/pen.24552

Winarno, F.G. (2008). Kimia pangan dan gizi. Bogor (ID): M-Brio Press.

Yap, W. F., Tay, V., Tan, S. H., Yow, Y. Y., \& Chew, J. (2019). Decoding antioxidant and antibacterial potentials of Malaysian green seaweeds: Caulerpa racemosa and Caulerpa lentillifera. Antibiotics, 8(152), 1-18. doi: 10.3390/antibiotics8030152 